Article

\title{
Fluorescent AgNCs Formed on Bifunctional DNA Template for Potassium Ion Detection
}

\author{
Patrycja Filipczuk $^{1}$ (D), Angelika Świtalska ${ }^{1}$, Joanna Kosman ${ }^{1} \mathbb{D}$, Grzegorz Nowaczyk ${ }^{2}$ (D) and Anna Dembska ${ }^{1, *(\mathbb{D})}$ \\ 1 Faculty of Chemistry, Adam Mickiewicz University, Uniwersytetu Poznańskiego 8, 61-614 Poznan, Poland; \\ patrycja.filipczuk@amu.edu.pl (P.F.); switalskaang@gmail.com (A.Ś.); kosman@amu.edu.pl (J.K.) \\ 2 NanoBioMedical Centre, Adam Mickiewicz University, Wszechnicy Piastowskiej 3, 61-614 Poznan, Poland; \\ nowag@amu.edu.pl \\ * Correspondence: aniojka@amu.edu.pl; Tel.: +48-61-829-1771
}

Citation: Filipczuk, P.; Świtalska, A.;

Kosman, J.; Nowaczyk, G.; Dembska,

A. Fluorescent AgNCs Formed on

Bifunctional DNA Template for

Potassium Ion Detection.

Chemosensors 2021, 9, 349. https://

doi.org/10.3390/chemosensors9120349

Academic Editor: Guo-Hui Pan

Received: 31 October 2021

Accepted: 7 December 2021

Published: 9 December 2021

Publisher's Note: MDPI stays neutral with regard to jurisdictional claims in published maps and institutional affiliations.

Copyright: (c) 2021 by the authors. Licensee MDPI, Basel, Switzerland. This article is an open access article distributed under the terms and conditions of the Creative Commons Attribution (CC BY) license (https:/ / creativecommons.org/licenses/by/ $4.0 /)$.

\begin{abstract}
In this study, we examined properties of silver nanoclusters, which are AgNCs stabilized by DNA oligonucleotide scaffold containing G-quadruplex-forming sequences: human telomeric (Tel22) or thrombin-binding aptamer (TBA). Thus, we obtained two fluorescent probes abbreviated as Tel22C12-AgNCs and TBAC12-AgNCs, which were characterized using absorption, circular dichroism and fluorescence spectroscopy. Both probes emit green and red fluorescence. The presence of silver nanoclusters did not destabilize the formed G-quadruplexes. The structural changes of probes upon binding $\mathrm{K}^{+}$or $\mathrm{Na}^{+}$ions cause quenching in their red emission. Green emission was slightly quenched only in the case of Tel22C12-AgNCs; on the contrary, for TBAC12-AgNC's green emission, we observed an increasing fluorescence signal. Moreover, the Tel22C12-AgNCs system shows not only a higher binding preference for $\mathrm{K}^{+}$over $\mathrm{Na}^{+}$, but it was able to monitor small changes in $\mathrm{K}^{+}$concentrations in the buffer mimicking extracellular conditions (high content of $\mathrm{Na}^{+}$ ions). These results suggest that Tel22C12-AgNCs exhibit the potential to monitor transmembrane potassium transport.
\end{abstract}

Keywords: silver nanoclusters; G-quadruplex; fluorescent probe; potassium sensing

\section{Introduction}

Silver nanoclusters (AgNCs) are a new class of fluorescent markers, the formation of which requires a suitable template, e.g., peptides, proteins, dendrimers, polymers, thiols or DNA oligonucleotides [1]. The cytosine base-rich oligonucleotides are the most commonly used template for $\mathrm{AgNC}$ preparation because the $\mathrm{C}-\mathrm{Ag}^{+}-\mathrm{C}$ complex has the best binding affinity [2-4]. So far, no binding of silver cations to DNA has been observed as a result of interactions with phosphate groups; therefore, it is believed that silver cations are bound only to DNA bases [5]. Further studies on the interaction of $\mathrm{Ag}^{+}$ions with various polymorphic DNA structures (cytosine-rich strands, duplex, i-motif and G-quadruplex) showed that the formation of DNA-Ag (I) complexes is a highly enthalpy-dependent process and negative enthalpy change is attributed to the exothermic coordination between silver ions and DNA bases [6]. The highest binding constants were obtained for oligonucleotides rich in cytosine base, followed by i-motifs and duplexes, while G-quadruplex matrices show the lowest silver ion binding constants [7]. The facile synthesis of silver nanoclusters (AgNCs) on DNA templates as well as their excellent brightness, good photostability and biocompatibility and small size compared to other fluorophores such as quantum dots or organic dyes make them the subject of extensive research resulting in numerous bioanalytical applications [8,9]. Moreover, the properly constructed oligonucleotide template enables obtaining fluorescent biosensors, which constitute a simple and cost-effective alternative to fluorophore-conjugated oligonucleotide probes. It is worth remembering that the bioanalytical application of fluorescent oligonucleotide probes is related not only to their ability 
to hybridize with the complementary strand but also to the discovered catalytic properties of some DNA fragments (DNAzymes) or the ability to bind other biomolecules (aptamers).

Thus, the use of DNA as a scaffold for nanoclusters is particularly convenient due to its structural versatility and easy integration with functional nucleic acids. For example, Dong et al. used aptamer-functionalized DNA-AgNCs for the detection of cocaine molecules with a LOD of $0.1 \mathrm{mM}$ [10]. Lately, Alipour et al. developed the dual-emitted cluster on DNA template to detect transgenic DNA (GMO). The designed system included DNA elements related to genetic modification in maize and was able to adopt a three-way junction structure upon hybridization with its target and G-rich sequence. The ratio of green to red fluorescence of the nanocluster exhibited a linear response with the target concentration in the range from 0.01 to $1 \mu \mathrm{M}$ [11]. Earlier, Feng et al. utilized AS1411 aptamer integrated with C-rich sequence (C10) to obtain biostable silver nanocluster for bioimaging specific tumor cells [12]. As it is known, AS1411 binds selectively to nucleolin, which is overexpressed on the surface of some malignant tumor cells $[13,14]$. The authors indicated that using L-conformation oligonucleotides as a scaffold enhanced the biostability of red emitting AgNCs; as a consequence, lower aptamer-AgNCs concentration is needed in order to observe fluorescence signals in vivo [12]. Martinez et al. introduced DNAAgNCs aptamer that can selectively bind thrombin and emits bright fluorescence $(\sim 60 \%$ quantum yield) with an emission peak at $~ 700 \mathrm{~nm}$ [15].

In their structure, aptamers and DNAzymes often contain non-canonical forms of DNA among which four-stranded structures such as G-quadruplexes (GQ) should be distinguished. GQ structures show many topological forms depending on their sequence and nature of the cation that stabilizes the structure [16-21]. In particular, the channel cavity site of the G-quadruplex structure prefers $\mathrm{K}^{+}$over $\mathrm{Na}^{+}$. Thus, by taking into account the stabilizing properties of the $\mathrm{K}^{+}$ion, a number of probes have been developed for monitoring the gradient of potassium ions in cellular conditions [22-27]. Among them, oligonucleotides with sequences of human telomere DNA or thrombin-binding aptamer (TBA) 15-mer $\mathrm{d}\left(\mathrm{G}_{2} \mathrm{~T}_{2} \mathrm{G}_{2} \mathrm{TGTG}_{2} \mathrm{~T}_{2} \mathrm{G}_{2}\right)$ are the most extensively employed as receptor layers [28].

Sensitive and selective detection of $\mathrm{K}^{+}$is essential to biomedical diagnosis. However, it is a challenge to selectively determine the extracellular $\mathrm{K}^{+}$concentration due to the presence of the large excess of sodium ion $\left(\mathrm{Na}^{+}\right)$in physiological conditions [29]. Biosensors using G-quadruplex DNAs as sensing elements for $\mathrm{K}^{+}$detections not only meet these criteria but also possess high biocompatibility and adjustable biodegradability.

The goal of the presented study was to obtain highly fluorescent AgNCs on cytosinerich DNA template (C12) integrated with a G-quadruplex DNA to form the new sensing probes to monitor $\mathrm{K}^{+}$changes in the extracellular environment. We assumed that the C-rich domain is mainly responsible for nanocluster formation and serves as the fluorescent tag, whereas the G-quadruplex forming domain serves as a receptor layout for potassium ions. For our purpose, with respect to the G-quadruplex forming part, we used two oligonucleotides bearing the sequence of human telomeric DNA (Tel22) and thrombin-binding aptamer (TBA). We obtained two fluorescent probes abbreviated as Tel22C12-AgNCs and TBAC12-AgNCs, respectively. As a result of the introduction of potassium ions, the Tel22 or TBA oligonucleotide fragment should assemble into a Gquadruplex secondary structure stabilized by the added metal cation. The structural changes were expected to have a significant impact on the specific interactions between GQ DNA and the formed silver nanoclusters on the C12 strand, thus modulating the fluorescence properties of DNA-AgNCs. We mainly utilized UV, fluorescence and CD spectroscopy techniques to monitor silver nanocluster formation and to perform spectral characterization of obtained AgNCs on Tel22C12 and TBAC12 scaffolds and the reference C12 oligonucleotide. Thermal denaturation experiments were also carried out to evaluate the stability of G-quadruplexes domain in Tel22C12-AgNCs and TBAC12-AgNCs systems and compared to free Tel22 and TBA G-quadruplexes. The effects of potassium and sodium ions on the spectral properties of Tel22C12-AgNCs and TBAC12-AgNCs were investigated. Finally, the performance of Tel22/C12-AgNCs as the fluorescent $\mathrm{K}^{+}$probe for extracellular 
measurements was examined by determining linear responses in the absence as well as presence of sodium ions.

\section{Materials and Methods}

\subsection{Materials}

Oligonucleotides (Table 1) were synthesized and purified on a high-affinity column by Genomed (Warsaw, Poland) and IBA (Göttingen, Germany). The concentrations of the nucleotides were adjusted by UV / Vis spectrophotometry. Tris(hydroxymethyl)aminomethane (TRIS) $(\geq 99.9 \%)$, dimethylarsinic acid sodium salt trihydrate $(\geq 98 \%)$, silver (I) nitrate $\left(\mathrm{AgNO}_{3}, \geq 99.0 \%\right)$, sodium borohydride $\left(\mathrm{NaBH}_{4}, \geq 98 \%\right)$, sodium chloride $(\mathrm{NaCl}, \geq 99.0 \%)$ potassium nitrogen $\left(\mathrm{KNO}_{3}, \geq 99.0 \%\right)$ and potassium chloride $(\mathrm{KCl}, \geq 99.0 \%)$ were purchased from Sigma-Aldrich. All stock solutions were prepared using MiliQ type purified water with Ultrapure Water Simplicity UV system and autoclaved using the Classic Prestige Medical Autoclave.

Table 1. The DNA oligonucleotide sequences used in this research.

\begin{tabular}{ccc}
\hline Name & Oligonucleotide Sequence & Company \\
\hline C12 & 5'-CCC CCC CCC CCC-3' & IBA \\
Tel22C12 & 5'-AGG GTT AGG GTT AGG GTT AGG G CC CCC CCC CCC C-3' & Genomed \\
TBAC12 & 5'-GGT TGG TGT GGT TGG CCC CCC CCC CCC-3' & Genomed \\
\hline
\end{tabular}

\subsection{Methods}

\subsubsection{DNA-Ag Nanoclusters Synthesis}

Silver nanoclusters were synthesized following the procedure of Ritchie et al. [30], which was slightly modified by us [31]. First, the corresponding DNA solution of $2.0 \mu \mathrm{M}$ was added to Tris-acetate buffer $(10 \mathrm{mM}, \mathrm{pH} 7.5)$. Next, the appropriate volume of $\mathrm{AgNO}_{3}$ solution of $10 \mathrm{mM}$ was added into the prepared corresponding DNA solution (1:1 molar ratio, $\mathrm{Ag}^{+} / \mathrm{C}$ base or $\mathrm{Ag}^{+} / \mathrm{GC}$ bases) and kept in the dark at $4{ }^{\circ} \mathrm{C}$ for $15 \mathrm{~min}$. After that time, the freshly prepared $\mathrm{NaBH}_{4}$ solution was added to the cold mixture and shaken vigorously for 1 min to reduce silver ions and to form AgNCs on DNA. Finally, the obtained solution was further stored (at least $1 \mathrm{~h}$ ) in the dark at $4{ }^{\circ} \mathrm{C}$ to prepare stable DNA-AgNCs.

\subsubsection{Fluorescence Spectroscopy}

Measurements of fluorescence spectra (emission spectra and excitation spectra) were performed by using an FP-8200 spectrofluorometer (Tokyo, Japan) equipped with a Peltier accessory and were carried out using $0.4 \times 1 \mathrm{~cm}$ quartz cuvette containing $1 \mathrm{~mL}$ of sample. Spectra were recorded at $25^{\circ} \mathrm{C}$ with record speed of $200 \mathrm{~nm} / \mathrm{min}$, with excitation and emission slits equal $5 \mathrm{~nm}$ and medium detector operation. The recording range of fluorescence spectra and their excitation and emission wavelengths were as follows:

- C12-AgNCs: Emission spectra of C12-AgNCs were collected at 3 excitation wavelengths: $\lambda_{\mathrm{ex}}=260 \mathrm{~nm}, \lambda_{\mathrm{ex}}=470 \mathrm{~nm}$ and $\lambda_{\mathrm{ex}}=580 \mathrm{~nm}$. Excitation spectra were collected at emission wavelength $\lambda_{\mathrm{em}}=630 \mathrm{~nm}$.

- Tel22C12-AgNCs: Emission spectra of Tel22C12-AgNCs were collected at 3 excitation wavelengths: $\lambda_{\mathrm{ex}}=260 \mathrm{~nm}, \lambda_{\mathrm{ex}}=470 \mathrm{~nm}$ and $\lambda_{\mathrm{ex}}=570 \mathrm{~nm}$. Excitation spectra were collected at 2 emission wavelengths: $\lambda_{\mathrm{em}}=550 \mathrm{~nm}$ and $\lambda_{\mathrm{em}}=620 \mathrm{~nm}$.

- TBAC12-AgNCs: Emission spectra of TBAC12-AgNCs were collected at 3 excitation wavelengths: $\lambda_{\mathrm{ex}}=260 \mathrm{~nm}, \lambda_{\mathrm{ex}}=470 \mathrm{~nm}$ and $\lambda_{\mathrm{ex}}=560 \mathrm{~nm}$. Excitation spectra were collected at 2 emission wavelengths: $\lambda_{\mathrm{em}}=550 \mathrm{~nm}$ and $\lambda_{\mathrm{em}}=610 \mathrm{~nm}$.

\subsubsection{Circular Dichroism (CD) Spectroscopy}

CD spectra were recorded on a Jasco J-820 Spectropolarimeter (Tokyo, Japan) equipped with a PTC-423L temperature controller at $25^{\circ} \mathrm{C}$. Each measurement was the average of three repeated scans recorded from 200 to $400 \mathrm{~nm}$ with a $10 \mathrm{~mm}$ quartz cell at a scan speed 
of $500 \mathrm{~nm} / \mathrm{min}$. The scan of the corresponding buffer solution was subtracted from the average scan for each sample.

\subsubsection{UV-Vis Absorption Spectroscopy}

Measurements of UV-Vis absorption spectra of the studied oligonucleotides were performed by using Jasco V-750 spectrophotometer (Tokyo, Japan) equipped with a Peltiertype temperature controller. Absorption spectra were recorded in the spectrum range of $220-800 \mathrm{~nm}$ with a record speed of $500 \mathrm{~nm} / \mathrm{min}$ at $25^{\circ} \mathrm{C}$.

\subsubsection{Transmission Electron Microscopy (TEM)}

TEM investigations were carried out by means of JEOL ARM 200F. TEM images were taken with an accelerating voltage of $200 \mathrm{kv}$ and at subångström resolution. The samples for examination by transmission electron microscopy were prepared by a deposition of a few droplets of silver nanoclusters solution onto holey carbon film supported by copper TEM grid.

\subsubsection{Studies upon Metal Cation Effect}

A typical investigation of metal cation effect in the concentration range of $0-0.15 \mathrm{M}$ consisted of successive additions of small portions of a concentrated solution of $3 \mathrm{M} \mathrm{KCl}$ or $3 \mathrm{M} \mathrm{NaCl}$ salt to $1 \mathrm{~mL}$ of DNA-AgNCs prepared $24 \mathrm{~h}$ earlier. After each addition, the solution was stirred, followed by thermally equilibration.

\section{Results}

The aim of our research was to verify the effect of potassium or/and sodium ions on the emission properties of AgNCs templated on oligonucleotide strands with the sequences 5'-AGG GGT AGG GTT AGG GTT AGG GCC CCC CCC CCC C-3' or 5'-GGT TGG TGT GGT TGG CCC CCC CCC CCC-3'. As reference, we used AgNCs synthesized on 12-mer oligonucleotide bearing only cytosines.

\subsection{The Prinicple Working Idea}

The strategy of the label-free monitor of potassium ion changes based on G-quadruplexes and AgNCs is presented in Figure 1. In this approach, the bifunctional sensor strand consists of two functional units, a 12-cytosine part (C12, marked blue) that serves as an AgNCs template and a G-quadruplex forming sequence (Table 1). C12 oligonucleotide possess the documented ability to be an effective template for bright red emission AgNCs with 2-7 Ag atoms [30].

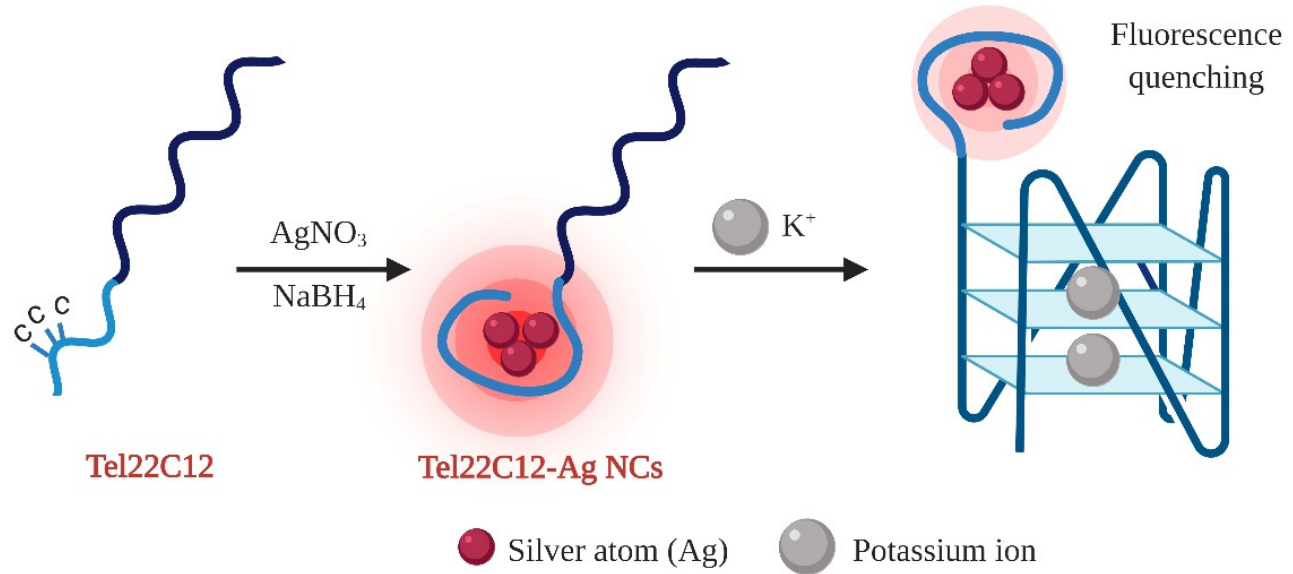

Figure 1. The demonstrative illustration shows the working idea of Tel22C12-AgNCs as potassium sensor. 
We used two different G-quadruplex forming sequences, which form different structural topologies in the presence of potassium ions, the human telomeric sequence AGGG(TTA GGG) 3 (Tel22) [16,17] and thrombin-binding aptamer GGTTGGTGTGGTTGG (TBA) [19,20]. We assumed that the addition of potassium or sodium ions induces G-quadruplex formation, causing remarkable changes in the fluorescence of silver nanocluster emissions.

\subsection{Rationalization of $A g N C s$ Templated on $C 12$ Integrated with $G Q$}

The synthesis of AgNCs on the DNA template was performed according to the procedure described by Petty [30] with slight modifications as in our previous study [31]. It is known that the sequence and length of the DNA oligonucleotide play an important role in determining the size of AgNCs and their optical properties, while the $\mathrm{Ag}^{+} / \mathrm{DNA}$ molar ratio determines fluorescence intensity [32]. As mentioned above, cytosine has the highest binding affinity for $\mathrm{Ag}^{+}$ions, but other bases, particularly guanine, can also be used as a template for DNA-AgNCs formation [33-35]. In our case, TBAC12 and Tel22C12 templates contain C-rich and G-rich domains; as a consequence, the formation of AgNCs on both fragments cannot be ruled out. Therefore, we decided to check how the $\mathrm{Ag}^{+} / \mathrm{DNA}$ ratio affects the spectral properties of Tel22C12-AgNCs or TBAC12 silver nanoclusters. We used a two different amounts of silver ions to generate silver nanoclusters. The ratio of 1:1 (C) means that there is $1 \mathrm{Ag}^{+}$ion per 1 cytosine base in the template strand; a ratio of 1:1 (CG) means that there is $1 \mathrm{Ag}^{+}$ion per sum of cytosine and guanine bases present in the template strand. In the case of reduction, the number of $\mathrm{BH}_{4}$ - was an equal amount of $\mathrm{Ag}^{+}$ions. Anyway, silver nanoclusters were prepared by mixing TBAC12 or Tel22C12 buffer solutions with $\mathrm{AgNO}_{3}$ and then $\mathrm{Ag}^{+}$was reduced by freshly prepared $\mathrm{NaBH}_{4}$. The formation of the nanoclusters during the reduction step was evident from the appearance of a yellowish color. First, the emission spectra of the as-prepared DNA-AgNCs were recorded with excitation at $260 \mathrm{~nm}$, which is near the absorption maxima of DNA bases. As shown in Figure 2, changing the DNA $/ \mathrm{Ag}^{+}$molar ratio affects fluorescence intensities but does not change the emission wavelength position $\left(\lambda_{\max }\right.$ around $560 \mathrm{~nm}$ and $\lambda_{\max }$ around $620 \mathrm{~nm})$. Silver nanoclusters synthesized at the ratio of $1: 1\left(\mathrm{Ag}^{+}:\right.$cytosine) show the best photoemission properties for both emission wavelengths (Figure 2A). Using a higher molar ratio of silver ions to DNA, the overall fluorescence intensity (Figure 2B) was quenched practically by $50 \%$ compared to the fluorescence obtained with ratio $1: 1\left(\mathrm{Ag}^{+} / \mathrm{C}\right)$.
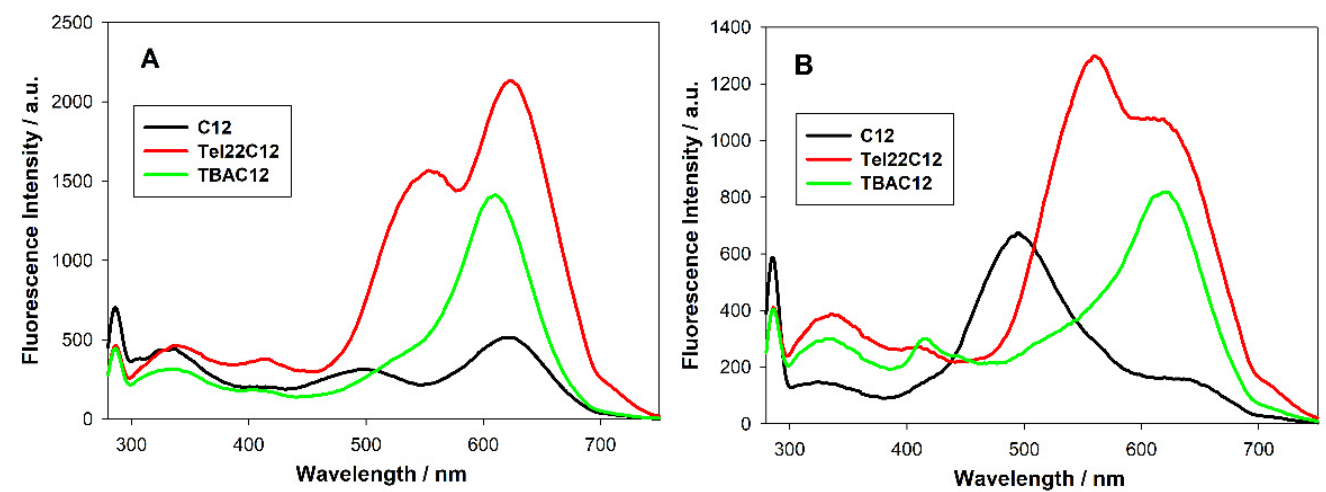

Figure 2. Emission spectra of studied DNA-AgNCs obtained by using different amounts of silver ions: (A) cytosine to $\mathrm{Ag}^{+}$ratio 1:1 $\left(\mathrm{Ag}^{+} / \mathrm{C}\right)$; (B) sum of cytosine and guanine to $\mathrm{Ag}^{+}$ratio 1:1 $\left(\mathrm{Ag}^{+} / \mathrm{CG}\right)$ for bifunctional templates and cytosine to $\mathrm{Ag}^{+}$ratio 2:1 $\left(\mathrm{Ag}^{+} / \mathrm{C}\right)$ for $\mathrm{C} 12$ template. Conditions: $2 \mu \mathrm{M}$ probe in $10 \mathrm{mM}$ Tris-acetate $(\mathrm{pH}=7.5)$ after $24 \mathrm{~h}$ since silver reduction.

The amount of $\mathrm{AgNO}_{3}$ used for the synthesis of silver nanoclusters also affects the absorption spectra (Figures S1-S3) and circular dichroism spectra (Figures S4 and S5). The most important factor is the presence of the absorption band at around $440 \mathrm{~nm}$, which is characteristic for AgNCs [29]. The stability of electronic transitions in the absorption spectra was also tested for at least a week (Figures S1-S3). It is worth noticing that the 
absorption spectra of Tel22C12-AgNCs (Figure S2) as well as TBAC12-AgNCs (Figure S3), apart from the UV bands and band at $440 \mathrm{~nm}$, possess a small band at 590 and $520 \mathrm{~nm}$, respectively. The latter band's intensity increases after $24 \mathrm{~h}$ contrary to decreasing intensity of bands at $440 \mathrm{~nm}$ and $350 \mathrm{~nm}$. In the case of the CD spectra recorded for Tel22C12AgNCs and TBAC12-AgNCs obtained with the ratio 1:1 $\left(\mathrm{Ag}^{+} / \mathrm{C}\right)$ and ratio 1:2 $\left(\mathrm{Ag}^{+} / \mathrm{C}\right)$, the differences are not so pronounced (Figures $\mathrm{S} 4$ and $\mathrm{S} 5$ ).

Morphology and size of Ag nanoclusters, obtained on C12 as well as Tel22C12 DNA scaffolds, were investigated using transmission electron microscopy (Figure S6). TEM images showed that the obtained silver nanoclusters are spherical in shape. The diameter of spherical C12-AgNCs oscillates around the values of $0.8 \mathrm{~nm}, 1.5 \mathrm{~nm}$ and $2 \mathrm{~nm}$. These diameter values are in agreement with previous reports $(<2 \mathrm{~nm})$. TEM images indicated the different size distribution of the nanoclusters, as was expected from spectroscopic studies. The microscopic TEM images obtained for Tel22C12-AgNCs (Figure S6C,D) revealed that the synthesized Ag nanoclusters have larger sizes, mainly with a diameter of $\sim 4.4 \mathrm{~nm}$ and $\sim 5 \mathrm{~nm}$, and confirmed earlier conclusions that the synthesized nanoclusters should have different sizes as two emission bands were observed, which correspond to the green $\left(\lambda_{\mathrm{em}}\right.$ around $550 \mathrm{~nm})$ and red $\left(\lambda_{\mathrm{em}}\right.$ around $\left.620 \mathrm{~nm}\right)$ color of fluorescence.

Therefore, the synthesis of silver nanoclusters on the DNA template was further carried out at a molar ratio of 1:1 (DNA(cytosine): $\mathrm{Ag}^{+}$). The final concentrations were $2 \mu \mathrm{M}$ DNA/24 $\mu \mathrm{M} \mathrm{Ag}^{+} / 24 \mu \mathrm{M} \mathrm{BH}_{4}{ }^{-}$, respectively.

\subsection{Circular Dichroism Studies upon AgNCs Templated on C12 Integrated with Tel22}

In order to investigate conformational changes in Tel22C12-AgNCs and C12-AgNCs systems, CD spectra of the oligonucleotides were measured before and after the addition of $\mathrm{Ag}^{+}$ions and reducing agent. In the absence of $\mathrm{Ag}^{+}$ions, $\mathrm{C} 12$ oligonucleotide (black line, Figure $3 \mathrm{~A}$ ) shows the expected position of the $\mathrm{CD}$ bands for unstructured oligonucleotides rich in cytosine base, i.e., a positive band at $285 \mathrm{~nm}$ and a negative band at around $265 \mathrm{~nm}[36,37]$. In the presence of $\mathrm{Ag}^{+}$ions (red line, Figure $3 \mathrm{~A}$ ), the $\mathrm{CD}$ spectrum is radically changed as a result of base- $\mathrm{Ag}^{+}$interaction, and two intense negative signals appear at $220 \mathrm{~nm}$ and $268 \mathrm{~nm}$. Reduction by $\mathrm{NaBH}_{4}$ induces a decreasing intensity of these two negative bands. In the case of the Tel22C12 oligonucleotide (black line, Figure 3B), which is also rich in guanine bases, the CD spectrum shows a positive band at $290 \mathrm{~nm}$ and two negative bands at $267 \mathrm{~nm}$ and $240 \mathrm{~nm}$. The addition of $\mathrm{AgNO}_{3}$ causes a large decrease in the intensity of the band at $290 \mathrm{~nm}$ with its simultaneous shift to $295 \mathrm{~nm}$, and two intense negative bands are visible at $220 \mathrm{~nm}$ and $268 \mathrm{~nm}$ (red line, Figure 3B). The main difference between the $\mathrm{CD}$ spectra of $\mathrm{C} 12-\mathrm{Ag}^{+}$and Tel22C12- $\mathrm{Ag}^{+}$systems is the presence of a positive band at approximately $290 \mathrm{~nm}$ for Tel22C12, which may indicate the formation of a G-quadruplex stabilized with silver ions.

The effect of silver ion reduction (by $\mathrm{NaBH}_{4}$ ) is more pronounced for Tel22C12-AgNCs than for C12-AgNCs. There is a decrease in the intensity of negative CD signals with a simultaneous shift of one of them from 220 to $236 \mathrm{~nm}$, and the positive band at $290 \mathrm{~nm}$ (attributed to G-quadruplex structure) is still present. It can be observed that within an hour after the reduction of $\mathrm{Ag}^{+}$ions by sodium borohydride, the formed DNA-AgNCs are transformed, which is manifested by changes in the CD spectrum. Regarding the stability of the CD spectra over time, it can be observed that with increasing incubation time from $1 \mathrm{~h}$ to $48 \mathrm{~h}$, there is a slight increase in the intensity of the CD signals obtained directly as a result of reduction by $\mathrm{NaBH}_{4}$. 

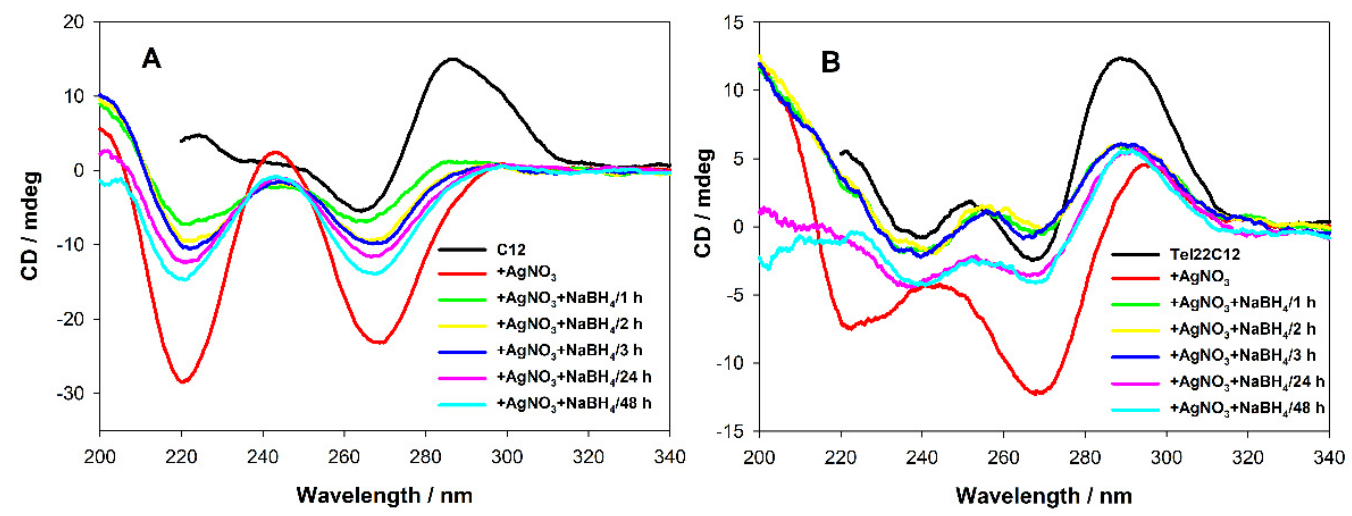

Figure 3. Circular dichroism spectra of studied systems before and after formation of C12AgNCs (A) or Tel22C12-AgNCs (B). Conditions: $2 \mu \mathrm{M}$ probe, $10 \mathrm{mM}$ Tris-acetate $(\mathrm{pH}=7.5),\left[\mathrm{Ag}^{+}\right]=\left[\mathrm{BH}_{4}^{-}\right]=$ $24 \mu \mathrm{M}$.

\subsection{Thermodynamic Stability of GQ Integrated with C12 Scaffold for AgNCs}

The G-quadruplex structures, despite lower binding constants, also provide a welldefined matrix for the formation of silver nanoclusters [7]. In our case, we focus on studies on the effect of the formed AgNCs on melting temperature $T_{m}$ of the Tel22-GQ DNA quadruplex or TBA-GQ DNA. The literature melting temperatures of TBA in the presence of $\mathrm{Na}^{+}$and $\mathrm{K}^{+}$are $24.0{ }^{\circ} \mathrm{C}$ and $53.0{ }^{\circ} \mathrm{C}$, respectively [38,39]. The literature $\mathrm{T}_{\mathrm{m}}$ for an oligonucleotide based on a 22-mer human telomeric DNA sequence (Tel22) in the presence of $\mathrm{K}^{+}$and $\mathrm{Na}^{+}$ions is equal to $62.0^{\circ} \mathrm{C}$ and $55.0{ }^{\circ} \mathrm{C}$, respectively [40]. Thermal stability and kinetics of G-quadruplex folding for Tel22C12-AgNCs nanoclusters and TBAC12-AgNCs nanoclusters synthesized in the presence of $\mathrm{K}^{+}(100 \mathrm{mM})$ or $\mathrm{Na}^{+}(100 \mathrm{mM})$ ions were evaluated using denaturation profiles recorded with absorbance at $295 \mathrm{~nm}$ as well as at $260 \mathrm{~nm}$. Temperatures at half transition $\left(T_{\mathrm{m}}\right)$ for all probes in the presence of $\mathrm{K}^{+}$and $\mathrm{Na}^{+}$ ions can be found in Table 2. As an example, Figure 4 shows the normalized denaturation profiles for G-quadruplexes formed by the Tel22C12 oligonucleotide in the presence of $\mathrm{K}^{+}$and $\mathrm{Na}^{+}$ions and GQ DNA/K ${ }^{+}$and GQ DNA/Na ${ }^{+}$formed on Tel22C12-AgNCs nanoclusters recorded at $260 \mathrm{~nm}$ (Figure 4A) and $295 \mathrm{~nm}$ (Figure 4B).

Table 2. Melting temperatures $\left(\mathrm{T}_{\mathrm{m}}\right)$ of $\mathrm{G}$-quadruplex-forming oligonucleotide probes determined from the melting profiles monitored at $295 \mathrm{~nm}$ in the presence of $\mathrm{K}^{+}$and $\mathrm{Na}^{+}$ions.

\begin{tabular}{ccc}
\hline Abbreviation of Probes & $\mathrm{Tm} / \mathrm{K}^{+}\left({ }^{\circ} \mathbf{C}\right)$ & $\mathrm{Tm} / \mathrm{Na}^{+}\left({ }^{\circ} \mathbf{C}\right)$ \\
\hline Tel22 & $62.0^{1}$ & $55.0^{1}$ \\
Tel22C12 & $37.5 / 65.0$ & $36.0 / 55.0$ \\
Tel22C12-AgNCs & 64.5 & 56.0 \\
TBA & $53.0^{1}$ & $24.0^{1}$ \\
TBAC12 & $18.2 / 52.0$ & - \\
TBA C12-AgNCs & 51.0 & 42.0 \\
\hline
\end{tabular}

${ }^{1}$ Determined by us in $10 \mathrm{mM}$ cacodylic buffer ( $\mathrm{pH}$ 7.5).

The denaturation profiles monitored at $\lambda=260 \mathrm{~nm}$ were difficult to interpret, because in this spectral range hyperchromic effects were observed for duplex as well as for GQ DNA structure denaturation. The monotonically increasing absorbance suggests that dsDNA and G4 DNA forms may coexist in the studied system (Figure 4A). The melting profiles determined at the diagnostic wavelength for G-quadruplexes $(295 \mathrm{~nm})$ allow the determination of two $\mathrm{T}_{\mathrm{m}}$ values for Tel22C12/ $\mathrm{K}^{+}\left(37.5^{\circ} \mathrm{C}\right.$ and $\left.65.0{ }^{\circ} \mathrm{C}\right)$. The lower $\mathrm{T}_{\mathrm{m}}$ $\left(37.5^{\circ} \mathrm{C}\right)$ could be interpreted as a result of an interaction between the Tel22 guanine base rich sequence and the $\mathrm{C} 12$ cytosine base rich fragment, which probably formed an incomplete duplex. In contrast, a melting point of $65.0^{\circ} \mathrm{C}$ suggests that the additional $\mathrm{C} 12$ sequence stabilizes the GQ DNA structure by $\sim 3^{\circ} \mathrm{C}$. Studies involving $\mathrm{Na}^{+}$ions confirm 
the concept of incomplete duplex with $\mathrm{T}_{\mathrm{m}}=36.0^{\circ} \mathrm{C}$ and G-quadruplex with $\mathrm{T}_{\mathrm{m}}=55.0^{\circ} \mathrm{C}$. The latter value practically does not differ from $\mathrm{T}_{\mathrm{m}} \mathrm{Tel} 22 / \mathrm{Na}^{+}\left(55.0^{\circ} \mathrm{C}\right)$.
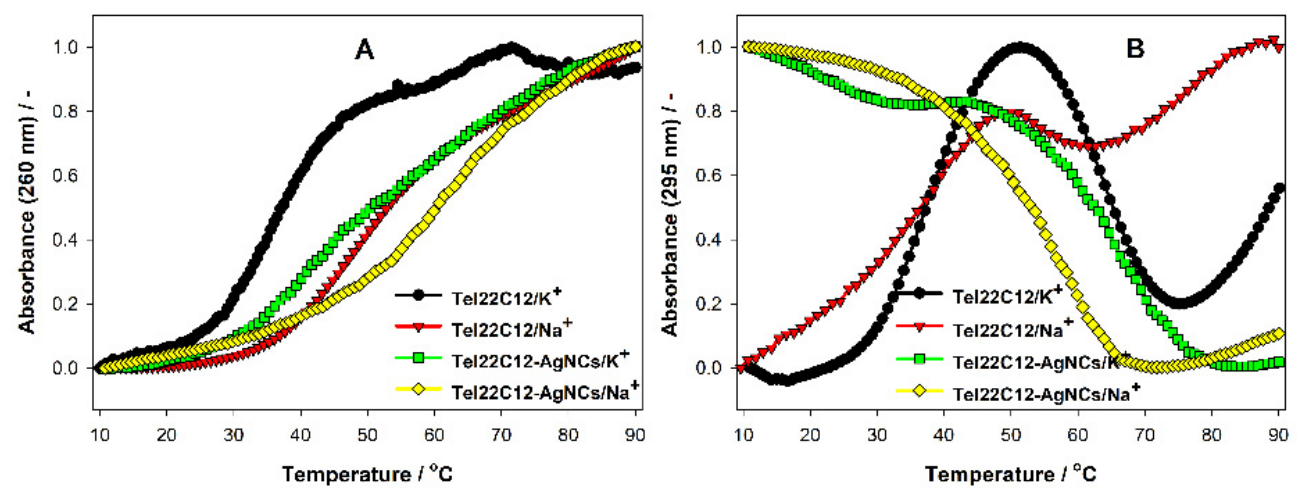

Figure 4. Normalized UV melting profiles of Tel22C12 and Tel22C12-AgNCs $(2 \mu \mathrm{M})$ in $10 \mathrm{mM}$ Trisacetate buffer $(\mathrm{pH}=7.5)$ containing $100 \mathrm{mM} \mathrm{NaCl}$ or $100 \mathrm{mM} \mathrm{KCl}$; monitored at $260 \mathrm{~nm}(\mathbf{A})$ or $295 \mathrm{~nm}(\mathbf{B})$.

Table 2 shows the $T_{m}$ values determined for GQ quadruplexes in the presence and absence of silver nanoclusters templated on DNA in solutions containing different cations. The melting temperatures of the four-stranded GQ DNA structures determined in the presence of the formed AgNCs structures practically do not differ from the $T_{m}$ for Tel22C12GQ DNA in both cases (with $\mathrm{K}^{+}$or $\mathrm{Na}^{+}$) but for TBAC12-GQ DNA only in the presence of $\mathrm{K}^{+}$. What is interesting is that the folding GQ structure by TBAC12 in the presence of $\mathrm{Na}^{+}$was not observed, whereas the TBA fragment folded into an even more stable GQ after formation TBAC12-AgNCs than free TBA in the presence of $100 \mathrm{mM} \mathrm{NaCl}$ (Figure S7). The complexity of TBAC12/Na ${ }^{+}$and TBAC12-AgNCs $/ \mathrm{Na}^{+}$systems is not clear for us. It is worth noting that for Tel22C12 as well as TBAC12 oligonucleotides, after serving as template for AgNCs, only $\mathrm{T}_{\mathrm{m}}$ for GQ DNA is observed, since the DNA segment rich in cytosine bases (C12) is fully involved in the stabilization of silver nanoclusters and is not able to interact with guanine-rich oligonucleotide (Tel22 or TBA).

\subsection{Temporal Stability of Fluorescent AgNCs Templated on C12 Integrated with GQ}

One of the most important properties of DNA-AgNCs is their good spectral stability over a relatively long time. This is essential for the use of AgNCs as fluorescent labels, e.g., in bioimaging [12,41]. The emission spectra of silver nanoclusters as well as absorption spectra, are complex and change over time, as shown earlier.

The full fluorescence spectra recorded from $1 \mathrm{~h}$ to 1 week after $\mathrm{NaBH}_{4}$ reduction for the tested systems are shown in Figures S8-S12. Figure 5 shows the dependence of the intensity of the emission bands in their maximum as a function of time for C12-AgNCs (Figure 5A), Tel22C12-AgNCs (Figure 5B) and TBAC12-AgNCs (Figure 5C), respectively. For C12-AgNCs nanoclusters, fluorescence reached its maximum at $\lambda_{\max }=634 \mathrm{~nm}$ after $24 \mathrm{~h}$ from the addition of $\mathrm{NaBH}_{4}$ and remained at a similar level for the next $24 \mathrm{~h}$ (Figure $5 \mathrm{~A}$ ). In the case of Tel22C12-AgNCs and TBAC12-AgNCs nanoclusters, the situation is more complicated because two emission bands have to be analyzed. For Tel22C12-agNCs, the highest value of fluorescence intensity at $\lambda_{\max }=621 \mathrm{~nm}\left(\lambda_{\mathrm{ex}}=570 \mathrm{~nm}\right)($ red circles, Figure 5B) was obtained after $24 \mathrm{~h}$ from the reduction, then it rapidly decreased, whereas the band with $\lambda_{\max }=555 \mathrm{~nm}$ (black circles, Figure 5B) for this nanosystem shows an inverse relationship in time. The signal with low intensity after $1 \mathrm{~h}$ is gradually amplified and reaches its maximum value after $72 \mathrm{~h}$ from reduction. In the case of TBAC12-AgNCs, the highest value of red emission was obtained after $1 \mathrm{~h}$ from reduction; however, it was gradually decreasing in time contrary to green emission, which slightly increased in time. Studies of the temporal stability of the fluorescence spectra indicate that fluorescence 
intensity gradually increases and reaches its maximum after $24 \mathrm{~h}$ from reduction by $\mathrm{NaBH}_{4}$ in the case of C12-AgNCs and Tel22C12-AgNCs.
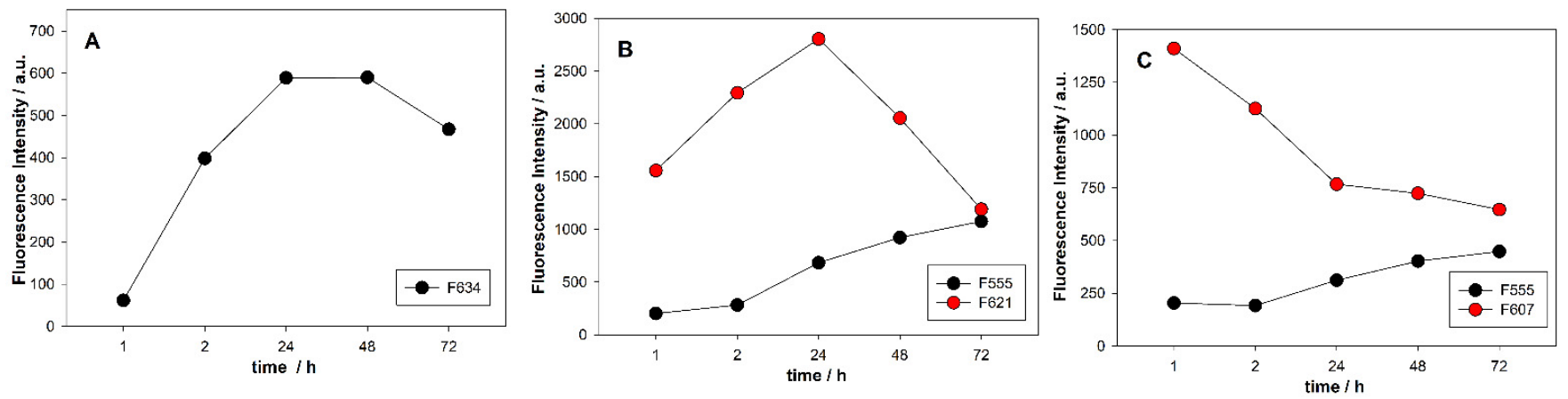

Figure 5. The evaluation emission properties of studied DNA-AgNCs in time: (A) C12AgNCs; (B) Tel22C12-AgNCs; (C) TBAC12-AgNCs. Conditions: $2 \mu \mathrm{M}$ probe in $10 \mathrm{mM}$ Tris-acetate $(\mathrm{pH}=7.5)$.

\subsection{Effect of Potassium and Sodium Ions on AgNCs Templated on C12 Integrated with GQ}

Knowing that G-quadruplexes have a high affinity for alkali metal ions, especially for $\mathrm{K}^{+}$ions, it is therefore expected that competing potassium ions will modulate the fluorescence of AgNCs. Figures 6 and 7 show the effect of $\mathrm{K}^{+}$(upper panels) and $\mathrm{Na}^{+}$ ions (lower panels) on the emission spectra of Tel22C12-AgNCs and TBAC12-AgNCs, which were recorded at two different excitation wavelengths (470 nm and 560 or $570 \mathrm{~nm}$ ). Upon excitation of Tel22C12-AgNCs at $\lambda_{\mathrm{ex}}=470 \mathrm{~nm}$, green fluorescence is active with a maximum of $\lambda_{\mathrm{em}}=560 \mathrm{~nm}$. Changing the excitation wavelength to $570 \mathrm{~nm}$ causes red emission with $\lambda_{\mathrm{em}}=620 \mathrm{~nm}$ to become active.
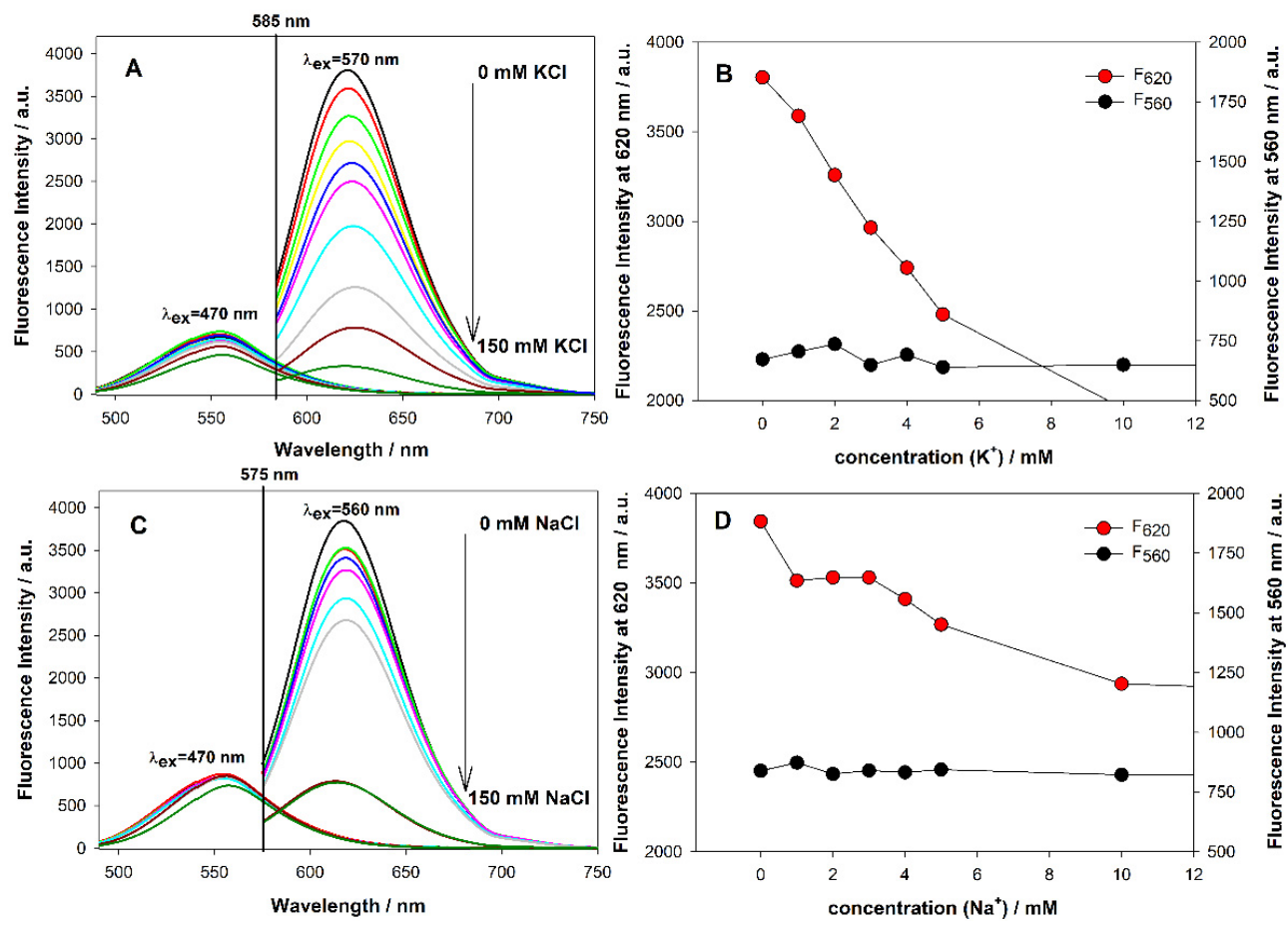

Figure 6. Effect of cations on fluorescence properties of Tel22C12-AgNCs: (A) emission spectra in presence of increasing $\mathrm{K}^{+}$concentration; (B) changes in maximum intensity of green and red fluorescence upon $\mathrm{K}^{+}$addition; (C) emission spectra in presence of increasing $\mathrm{Na}^{+}$concentration; (D) changes in maximum intensity of green and red fluorescence upon $\mathrm{Na}^{+}$addition. Conditions: $2 \mu \mathrm{M}$ probe in $10 \mathrm{mM}$ Tris-acetate $(\mathrm{pH}=7.5)$ after $24 \mathrm{~h}$ from silver reduction. 

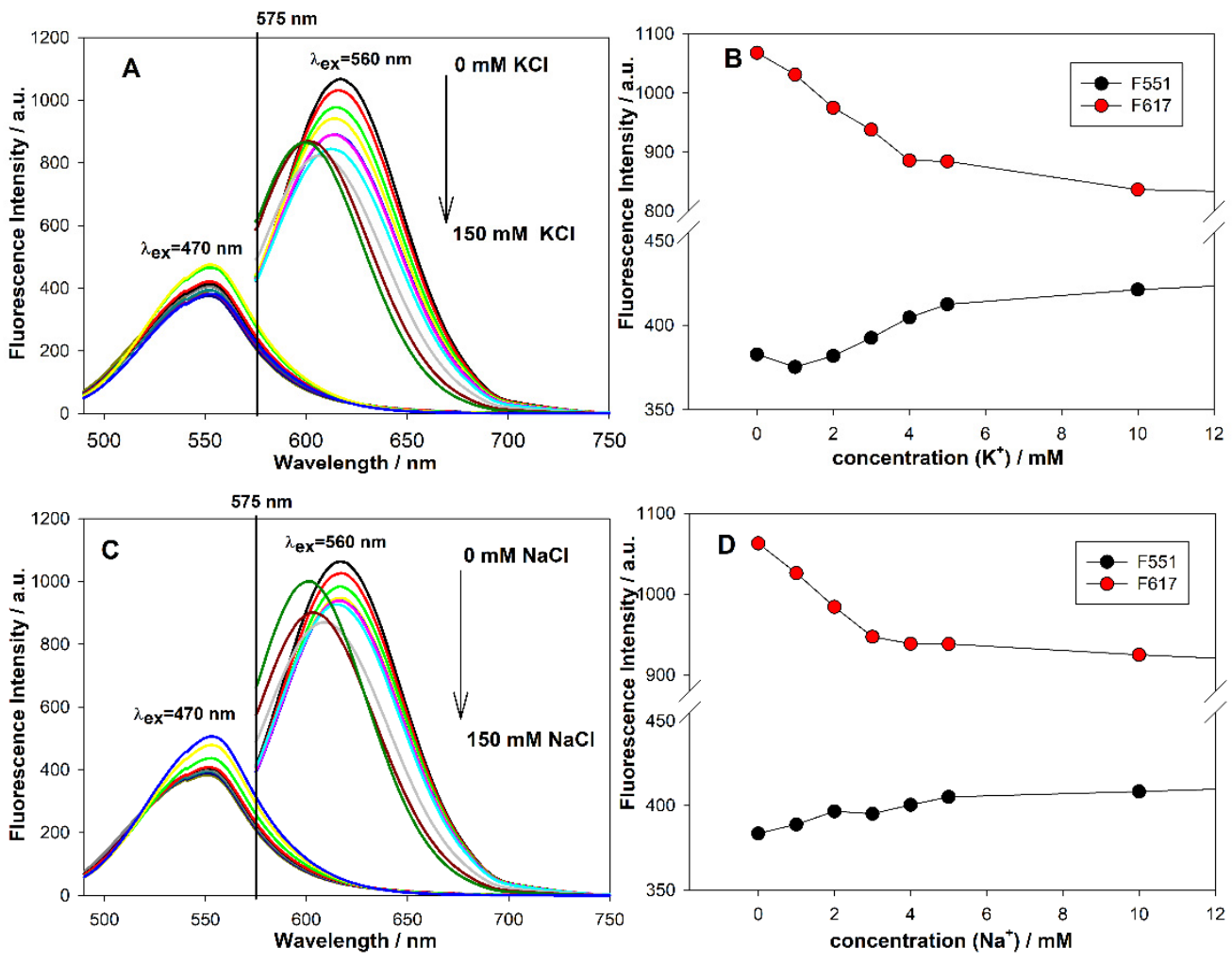

Figure 7. Effect of cations on fluorescence properties of TBAC12-AgNCs: (A) emission spectra in presence of increasing $\mathrm{K}^{+}$concentration; (B) changes in maximum intensity of green and red fluorescence upon $\mathrm{K}^{+}$addition; (C) emission spectra in presence of increasing $\mathrm{Na}^{+}$concentration; (D) changes in maximum intensity of green and red fluorescence upon $\mathrm{Na}^{+}$addition. Conditions: $2 \mu \mathrm{M}$ probe in $10 \mathrm{mM}$ Tris-acetate $(\mathrm{pH}=7.5)$ after $24 \mathrm{~h}$ since silver reduction.

Subsequent additions of $\mathrm{K}^{+}$ions cause a gradual decrease in the Tel22C12-AgNCs fluorescence signal regardless of the excitation wavelength used. For both emission bands $\left(\lambda_{\mathrm{em}}=560 \mathrm{~nm}\right.$ and $\lambda_{\mathrm{em}}=620 \mathrm{~nm}$ ), fluorescence intensity drops sharply with increasing concentrations of $\mathrm{K}^{+}$from 1 to $10 \mathrm{mM}$ and much slower in the range of higher $\mathrm{K}^{+}$concentrations $(10-150 \mathrm{mM})$ (Figure $6 \mathrm{~A}, \mathrm{~B})$. On the other hand, the additions of $\mathrm{Na}^{+}$ions cause less radical changes in Tel22C12-AgNCs fluorescence (Figure 6C,D).

In the $1-50 \mathrm{mM} \mathrm{Na}^{+}$range, slight and non-linear changes in the red fluorescence intensity of Tel22C12-AgNCs and a sharp decrease in red emission in the presence of 100-150 $\mathrm{mM} \mathrm{Na}^{+}$were observed (Figure 6C,D). In the case of the TBAC12-AgNCs system, the influence of $\mathrm{K}^{+}$and $\mathrm{Na}^{+}$ions on its emission is comparable. In both cases, we observed decreasing fluorescence intensity at $617 \mathrm{~nm}$ when increasing the metal ion concentration in the 1-50 $\mathrm{mM}$ range. However, by analyzing the long-wave emission spectra $\left(\lambda_{\mathrm{em}}=617 \mathrm{~nm}\right)$ of TBAC12-AgNCs in the presence of alkali metal ions, there is a blue shift of maximum in the presence of $100-150 \mathrm{mM} \mathrm{K}^{+}$or $\mathrm{Na}^{+}$ions (Figure $7 \mathrm{~A}, \mathrm{C}$ ), which suggest the clear redistribution of AgNCs on TBAC12 template. On the contrary, the green emission band $\left(\lambda_{\mathrm{em}}=551 \mathrm{~nm}\right)$ of TBAC12-AgNCs indicates a slight enhancement in the presence of alkali metal ions (black dots in Figure 7B,D).

In the experiments aimed at studying the effect of cations, the additions of $\mathrm{KCl}$ and $\mathrm{NaCl}$ salts were used; however, it is known that $\mathrm{Cl}^{-}$ions can interact with $\mathrm{Ag}^{+}$cations to form an $\mathrm{AgCl}$ precipitate with very low solubility in water $\left(\mathrm{Ir}=1.8 \times 10^{-10}\right)$ or they can adsorb on silver nanoclusters. In order to check whether the type of salt counter-ion reduces the fluorescence of Tel22C12-AgNCs, additional measurements were carried out with the use of $\mathrm{KNO}_{3}$ salt. Tel22C12-AgNCs emission was quenched by $\mathrm{K}^{+}$ions coming from $\mathrm{KNO}_{3}$ salt. It turned out that the type of salt counter-ion did not affect the efficiency of this process, as the obtained $\mathrm{F} 620 \mathrm{vs}$. $\mathrm{Cl}^{-} / \mathrm{NO}_{3}{ }^{-}$profiles practically overlap (Figure S13). 
The quenching properties of $\mathrm{K}^{+}$and $\mathrm{Na}^{+}$ions were also verified by measuring the absorption spectra recorded under analogous experimental conditions. The effect of $\mathrm{K}^{+}$ions is shown in Figures S14a and S15a, and the effect of $\mathrm{Na}^{+}$is shown in Figures S14b and S15b for Tel22C12-AgNCs and TBAC12-AgNCs, respectively. It can be observed that both cations cause a decrease in the absorption bands below $500 \mathrm{~nm}$ and practically quench the absorption at $580 \mathrm{~nm}$ in the presence of $100 \mathrm{mM}$ salt. The strong quenching of the absorbance at $580 \mathrm{~nm}$ suggests that the decrease in AgNCs fluorescence at $620 \mathrm{~nm}$ upon addition of $\mathrm{K}^{+}\left(\right.$or $\left.\mathrm{Na}^{+}\right)$ions is mainly due to the disappearance of the electronic transition at this wavelength.

Circular dichroism spectra should confirm the formation of the $\mathrm{K}^{+} / \mathrm{G}$-quadruplex complex in the DNA-AgNCs system as a result of the addition of $\mathrm{K}^{+}\left(\right.$or $\left.\mathrm{Na}^{+}\right)$ions. Figure S16 show the CD spectra of the Tel22C12-AgNCs system in the presence of increasing concentrations of $\mathrm{KCl}$ and $\mathrm{NaCl}$. The synthesis of silver nanoclusters on the Tel22C12 results in DNA-AgNCs possessing a CD spectrum with a positive signal at $290 \mathrm{~nm}$ and two negative signals at $265 \mathrm{~nm}$ and $240 \mathrm{~nm}$. Contrary to expectations, the gradual addition of $\mathrm{K}^{+}$or $\mathrm{Na}^{+}$ions in the concentration range of 1-150 mM has no significant effect on the band pattern in CD spectra. The analogous results were obtained for the CD spectra of TBAC12-AgNCs system in the presence of increasing concentrations of $\mathrm{KCl}$ and $\mathrm{NaCl}$, as shown in Figure S17.

These results suggest that both DNA-AgNCs systems probably contain Ag(I)/Gquadruplex complexes, which are transformed into a GQ form stabilized by potassium or sodium ions, but this process does not cause significant changes in the CD band characteristic of GQ DNA at approximately $290 \mathrm{~nm}$.

\subsection{Feasibility of Proposed Systems to Detect $K^{+}$Ions}

The studies on the effect of potassium and sodium cations on spectral properties of Tel22C12 and TBAC12 helped us to select the potentially better sensors in terms of sensitivity and selectivity towards potassium ions. Thus, the feasibility of the proposed system to detect $\mathrm{K}^{+}$ions in extracellular conditions was further evaluated for Tel22C12-AgNCs. First, in order to assess the analytical parameters of the $\mathrm{K}^{+}$ion detection system, the Tel22C12AgNCs probe response (fluorescence intensity) was tested at different concentrations of the analyte $\left(\mathrm{K}^{+}\right.$ions) in the concentration range of $0-150 \mathrm{mM}$ at $\lambda_{\mathrm{em}}=620 \mathrm{~nm}\left(\lambda_{\mathrm{ex}}=570 \mathrm{~nm}\right)$. As shown in Figure $8 \mathrm{~A}$, fluorescence intensity gradually decreases with increasing $\mathrm{K}^{+}$ ion concentrations. Based on emission spectra, we constructed the Stern-Volmer plot, which illustrates the quenching effect of $\mathrm{K}^{+}$ions on the emission of Tel22C12-AgNCs (Figure $8 \mathrm{~B}$, where $\mathrm{F}_{0}$ means fluorescence intensity of Tel22C12-AgNCs without $\mathrm{K}^{+}$ions and $\mathrm{F}$-fluorescence intensity after addition of potassium ions). A good linear relationship of Tel22C12-AgNCs fluorescence with $\mathrm{K}^{+}$concentration was observed over the entire tested range from 1 to $10 \mathrm{mM}\left(\mathrm{R}^{2}=0.987\right)$ and from 10 to $150 \mathrm{mM} \mathrm{K}\left(\mathrm{R}^{2}=0.977\right)$ and the limit of detection (LOD) was calculated-0.37 $\mathrm{mM}$.

These parameters indicate the potential usefulness of the developed probe Tel22C12AgNCs for measuring and monitoring the gradient of potassium ions in cell systems; however, for the sensor to be useful to monitor $\mathrm{K}^{+}$levels in extracellular conditions, it is essential to distinguish small variations in $\mathrm{K}^{+}$concentration in the presence of $150 \mathrm{mM} \mathrm{Na}^{+}$ concentration. Therefore, we added $150 \mathrm{mM} \mathrm{NaCl}$ to the Tel22C12-AgNCs prepared $24 \mathrm{~h}$ earlier in buffer without metal cations. Next, we measured the changes in the fluorescence spectra of Tel22C12-AgNCs in the presence of $150 \mathrm{mM} \mathrm{Na}^{+}$upon titration with $\mathrm{K}^{+}$ions in the 1-10 mM concentration range (as shown in Figure $8 \mathrm{C}$ ). As stated previously, the SternVolmer curve was plotted using ratio of $\mathrm{F}_{0} / \mathrm{F}$ versus potassium concentration, where $\mathrm{F}_{0}$ was fluorescence intensity of Tel22C12-AgNCs in the presence of $150 \mathrm{mM} \mathrm{NaCl}$, and F was the fluorescence intensity after the addition of potassium ions under the same conditions. As shown in Figure 8D, the linear range of the analytical response of Tel22C12-AgNCs ranges from 1 to $10 \mathrm{mM} \mathrm{K}^{+}$concentration $\left(\mathrm{R}^{2}\right.$ 0.995) with LOD established at $0.4 \mathrm{mM}$ and a sensitivity of $0.19 \mathrm{mM}^{-1}$. In the literature, potassium probes with detection limit below 
$1 \mu \mathrm{M}$ and even equal to $2.37 \mathrm{pM}$ can be found ([42] and cited herein). For us, it is important that the Tel22C12-AgNCs probe shows a linear working range for $\mathrm{K}^{+}$detection from 1 to $10 \mathrm{mM}$ (with LOD $0.4 \mathrm{mM}$ ) in the presence of $150 \mathrm{mM} \mathrm{Na}^{+}$, which covers a clinically important concentration region of $\mathrm{K}^{+}$(3.5 to $\left.5.5 \mathrm{mM}\right)$ under extracellular conditions [43].
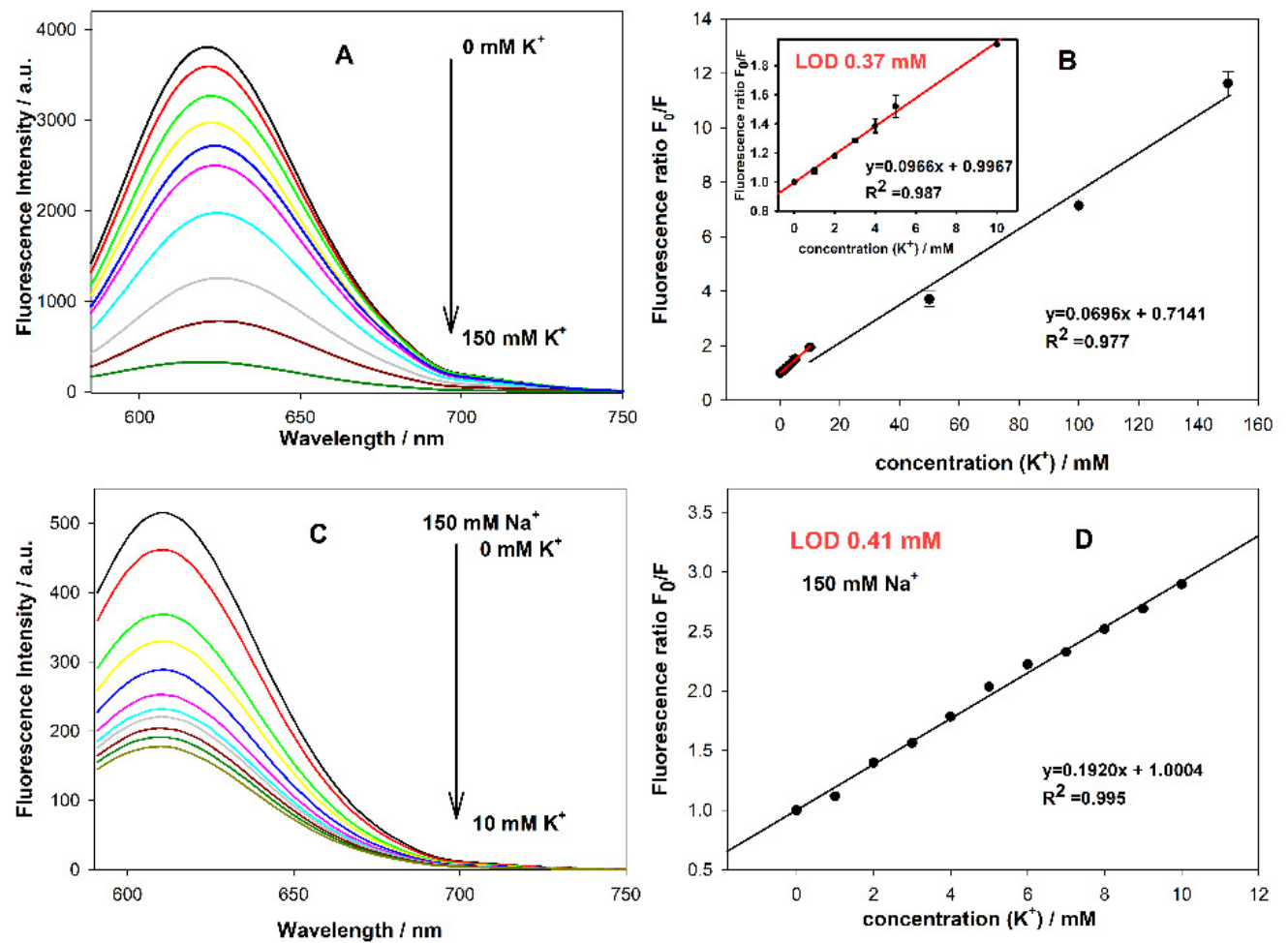

Figure 8. Fluorescence response of the Tel22C12-AgNCs in buffers $\mathrm{w} / \mathrm{o}$ and with sodium ions at different $\mathrm{K}^{+}$concentrations: (A) the emission spectra of Tel22C12-AgNCs upon adding increasing concentrations of $\mathrm{K}^{+}$ions $(0-150 \mathrm{mM})$ and (B) corresponding Stern-Volmer plot showing $\mathrm{K}^{+}$quenching effect on Tel22C12-AgNCs emission spectra with $\lambda_{\max }=620 \mathrm{~nm}$ in the absence of sodium ions. Insert showing linear relationship in concentration ranges from 0 to $10 \mathrm{mM} \mathrm{K}^{+}$; (C) the emission spectra of Tel22C12-AgNCs in buffer with $150 \mathrm{mM} \mathrm{NaCl}$ upon adding increasing concentrations of $\mathrm{K}^{+}$ ions (0-10 mM) and (D) corresponding Stern-Volmer plot showing $\mathrm{K}^{+}$quenching effect on Tel22C12AgNCs emission spectra with $\lambda_{\max }=610 \mathrm{~nm}$ in the presence of sodium ions. Conditions: $2 \mu \mathrm{M}$ probe in $10 \mathrm{mM}$ Tris-acetate $(\mathrm{pH}=7.5)$ after $24 \mathrm{~h}$ from silver reduction in buffer $\mathrm{w} / \mathrm{o}$ metal cations.

\section{Discussion}

DNA-AgNCs silver nanoclusters were synthesized on single-stranded DNA templates with two integrated domains: cytosine-rich DNA template (C12) attached to 3' end of G-quadruplex forming sequence. For our purposes, we used human telomeric-related sequence and TBA sequence, both of which are widely explored to compose potassium sensing probes. First, the formation of nanoclusters during the reduction step was evident due to the appearance of a yellow color as the main distinguishing feature of silver nanoclusters in the presence of an intense narrow band at a wavelength of approximately $440 \mathrm{~nm}$ [30]. On the other hand, the absorption spectra of dark silver nanoparticles ( $>10 \mathrm{~nm}$ ) show only one wide peak at $\lambda_{\max }=405 \mathrm{~nm}$. As expected, in the case of examined silver nanoclusters, an intense narrow band was observed at approximately $440 \mathrm{~nm}$, and a few others bands were also observed: at $350 \mathrm{~nm}, 500 \mathrm{~nm}$ and $650 \mathrm{~nm}$ for C12-AgNCs (or at $355 \mathrm{~nm}$ and $590 \mathrm{~nm}$ for Tel22C12-AgNCs as well as $355 \mathrm{~nm}$ and $520 \mathrm{~nm}$ for TBAC12-AgNCs). These bands are considered to be an indicator of the formation of AgNCs nanoclusters. The intensity of bands changes over time, which indicates the presence of the several types of AgNCs that differ in size/shape and number of silver atoms. These conclusions were supported by TEM images. The amount of $\mathrm{AgNO}_{3}$ used for the synthesis of silver nanoclusters affects the 
absorption spectra as well as CD and emission spectra. In the latter one, the excitation at $260 \mathrm{~nm}$ reveals that red emission was observed and dominant at least $1 \mathrm{~h}$ from the reduction step. However, the overall emission was higher in the case of Tel22C12-AgNCs as well as TBAC12-AgNCs obtained at a ratio of $1: 1\left(\mathrm{Ag}^{+} / \mathrm{C}\right)$ in comparison with nanoclusters obtained at a ratio of 1:1 ( $\left.\mathrm{Ag}^{+} / \mathrm{CG}\right)$. Moreover, it should be noted that the fluorescence comes from the formed nanoclusters and not from the DNA- $\mathrm{Ag}^{+}$complexes, as evidenced by the lack of emission in the solutions without $\mathrm{NaBH}_{4}$ reduction agent.

In order to investigate the conformational changes in the Tel22C12-AgNCs or TBAC12$\mathrm{AgNC}$ systems and in reference $\mathrm{C} 12-\mathrm{AgNC}, \mathrm{CD}$ spectra of the oligonucleotides were measured. The main difference between the $C D$ spectra of these systems and reference is the presence of a positive band at approximately $290 \mathrm{~nm}$ for Tel22C12 and TBAC12, which may indicate the formation of a G-quadruplex stabilized with silver ions. Moreover, the lack of changes in $\mathrm{CD}$ spectra after further addition of $\mathrm{KCl}$ (or $\mathrm{NaCl}$ ) to Tel22C12-AgNCs or TBAC12-AgNCs solutions suggests that the displacement of silver ions from the GQ complex by $\mathrm{K}^{+}$(or $\mathrm{Na}^{+}$) may have occurred. On the other hand, the performed studies on the stability of G-quadruplexes created by the Tel22C12 or TBAC12 oligonucleotide prior to the formation silver nanoclusters informed that the formed AgNCs had no destabilizing effect on the studied GQ DNA structures.

Taking into account the possible application of our systems (Tel22C12-AgNCs and TBAC12-AgNCs) as fluorescent probes for monitoring potassium ions in extracellular conditions, we focused on investigating their fluorescent properties without and in the presence of $\mathrm{K}^{+}$or $/$and $\mathrm{Na}^{+}$cations. As we mentioned, the obtained fluorescence spectra indicate that the emission wavelength of DNA-AgNCs nanoclusters synthesized in aqueous solutions is strongly dependent on the sequence of DNA oligonucleotides, which is also confirmed by the literature data [44]. The both studied systems emit stronger fluorescence in comparison with silver nanoclusters templated on reference $\mathrm{C} 12$ oligonucleotide. It was found that a matrix based on intramolecular G-quadruplexes with anti-parallel topology results in AgNCs with higher fluorescence efficiency compared to GQ DNA with parallel and hybrid topology. The loops connecting G-tetrads also influence the photoemission properties of AgNCs; thus, the best effect was obtained when the loops were rich in adenine bases, not thymine, which is consistent with their $\mathrm{Ag}^{+}$binding affinity. The $\mathrm{K}^{+}$-stabilized human telomeric GQ DNA has a hybrid structure with two lateral loops and one sidewise loop [16,17], whereas sodium-stabilized antiparallel basket-type human telomeric G-quadruplex structure possesses one diagonal and two lateral loops [18]. The potassium-stabilized anti-parallel chair-type TBA GQ structure consists of two G-tetrads linked by an edge-wise loop and two lateral loops [20]. However, in our case, the overall fluorescence of Tel22C12-AgNCs is stronger than that of TBAC12-AgNCs. These results suggest the predominant role of the C-rich domain, attached to the $3^{\prime}$ terminus of TBA or Tel22, in the formation of fluorescent silver nanoclusters.

The $N$ (3) positions of the cytosine and the $N(7)$ guanine are usually involved in silver interactions with DNA bases [2,5,45]. For G-quadruplex structures, Ag ions compete for guanine $\mathrm{N}(7)$ sites because these positions are also involved in the bond formation of Hoogsteen-type hydrogen in the G-quartet [3]. Taking into account that GQs have a high affinity for alkali metal ions, the effect of potassium and sodium ions was studied. The most pronounced quenching effect of $\mathrm{K}^{+}$or $\mathrm{Na}^{+}$ions was observed on red emission (with a maximum above $600 \mathrm{~nm}$ for Tel22-related or TBA-related probes). In the case of green emission emitted by TBAC12-AgNCs, we observed a slight increase in fluorescence upon metal ion addition. In the case of Tel22C12-AgNCs, the influences of $\mathrm{Na}^{+}$ions on the emission bands are less visible compared to the effect of potassium ions. It is known that $\mathrm{Na}^{+}$ions also stabilize four-stranded structures; however, the stability constant of the GQ-DNA- $\mathrm{Na}^{+}$complex is much lower than that of the potassium quadruplex. The observed quenching effects may be explained by the process of creating $\mathrm{K}^{+}$or $\mathrm{Na}^{+} / \mathrm{G}-$ quadruplex complexes by Tel22 or TBA strands. Pre-generated AgNCs are stabilized not only by interaction with the cytosines in $\mathrm{C} 12$ but also by the guanines in the Tel22 or TBA 
fragment. The competitive formation of the G-quadruplex, in the presence of $\mathrm{K}^{+}$or $\mathrm{Na}^{+}$ ions, reduces the stabilizing effect of guanines, which is manifested by the quenching of AgNCs fluorescence. This assumption is consistent with the affinity of potassium and sodium ions for GQ DNA and with the comparable fluorescence intensity values for C12-AgNCs and Tel22C12-AgNCs or TBAC12-AgNCs in the presence of $150 \mathrm{mM} \mathrm{KCl}$.

Although the red fluorescence emission of both systems (Tel22C12-AgNCs or TBAC12$\mathrm{AgNCs}$ ) was quenched by sodium or potassium ions, only in the case of Tel22C12-AgNCs were the observed changes clearly regular. Thus, the gradual decrease in Tel22C12-AgNCs fluorescence as well as a good linear relationship between quenching efficiency and $\mathrm{K}^{+}$ concentration in the range of 1-150 $\mathrm{mM}$ encouraged us to check the feasibility of this system in order to detect changes in $\mathrm{K}^{+}$concentration in the access of $\mathrm{Na}^{+}$ions. In the presence of $150 \mathrm{mM} \mathrm{NaCl}$, we obtained a Stern-Volmer plot with linear behavior in the range from 1 to10 $\mathrm{mM} \mathrm{K}^{+}\left(\mathrm{R}^{2}=0.995\right)$ and with an LOD value established at $0.4 \mathrm{mM}$. These results clearly indicate that Tel22C12-AgNCs exhibit the potential to monitor transmembrane potassium transfer. One should remember that the intracellular potassium concentration is approximately forty-fold greater than the extracellular concentration, and any maneuver that would result in the release of a small amount of intracellular potassium will erroneously raise serum potassium. The normal range for serum potassium is narrow ( 3.5 to $5.5 \mathrm{mM}$ ), and a minor departure from this range (by less than $1.0 \mathrm{mM}$ ) is associated with significant morbidity and mortality [43].

\section{Conclusions}

Dual-emitting clusters of $\mathrm{Ag}$ atoms can be successfully obtained on a bifunctional oligonucleotide consisting of cytosine-rich DNA template (C12) attached to 3' end of Gquadruplex forming sequence. Our studies indicate that the competitive formation of G-quadruplex structure as a result of the complexation of potassium or sodium ions has a significant impact on the emission properties of silver nanoclusters. The proper choice of G-quadruplex forming sequence makes it possible to obtain a silver nanocluster system that not only shows a higher binding preference for $\mathrm{K}^{+}$over $\mathrm{Na}^{+}$but also is able to monitor small changes in $\mathrm{K}^{+}$concentration in the extracellular conditions (high content of $\mathrm{Na}^{+}$ ions). In our case, Tel22C12-AgNCs including the human telomeric sequence known to form GQ exhibit the potential to monitor transmembrane potassium transfer. The limit of detection for the Tel22C12-AgNCs K+ sensor is at a value of $4.0 \times 10^{-4}$, with the linear range between $1.0 \times 10^{-3}$ and $1.0 \times 10^{-2} \mathrm{M}$ in the $1.5 \times 10^{-1} \mathrm{M}$ solution of $\mathrm{Na}^{+}$ions. The further integration Tel22C12-AgNCs with a cholesterol moiety is planned in order to create a new sensing probe with the ability to anchor to the living cell membrane and, as a consequence, to serve as bioimaging tool for the visualization of transmembrane transport of $\mathrm{K}^{+}$cation.

Supplementary Materials: The following are available online at https:/ /www.mdpi.com/article/ 10.3390/chemosensors9120349/s1, Figure S1: Absorption spectra of C12-AgNCs with cytosine to $\mathrm{Ag}^{+}$ratio 1:0.5 (a), 1:1 (b) and 1:2 (c) $\left(\mathrm{Ag}^{+} / \mathrm{C}\right)$. Changes in time of absorbance value at $\lambda=440 \mathrm{~nm}$ (d); Figure S2: Absorption spectra of Tel22C12-AgNCs with cytosine to $\mathrm{Ag}^{+}$ratio 1:1 $\left(\mathrm{Ag}^{+} / \mathrm{C}\right)$ (a) or cytosine and guanine to $\mathrm{Ag}^{+}$ratio 1:1 $\left(\mathrm{Ag}^{+} / \mathrm{CG}\right)(\mathrm{b})$; Figure S3: Absorption spectra of TBAC12AgNCs with cytosine to $\mathrm{Ag}^{+}$ratio 1:1 $\left(\mathrm{Ag}^{+} / \mathrm{C}\right)$ (a) or cytosine and guanine to $\mathrm{Ag}^{+}$ratio 1:1 $\left(\mathrm{Ag}^{+} / \mathrm{CG}\right)$ (b); Figure S4: Circular dichroism spectra of Tel22C12-AgNCs with cytosine to $\mathrm{Ag}^{+}$ratio 1:1 $\left(\mathrm{Ag}^{+} / \mathrm{C}\right)$ (a) or cytosine and guanine to $\mathrm{Ag}^{+}$ratio 1:1 ( $\left.\mathrm{Ag}^{+} / \mathrm{CG}\right)$ (b); Figure S5: Circular dichroism spectra of TBAC12-AgNCs with cytosine to $\mathrm{Ag}^{+}$ratio $1: 1\left(\mathrm{Ag}^{+} / \mathrm{C}\right.$ ) (a) or cytosine and guanine to $\mathrm{Ag}^{+}$ratio 1:1 ( $\left.\mathrm{Ag}^{+} / \mathrm{CG}\right)(\mathrm{b})$; Figure S6: Transmission electron microscopy (TEM) images of the nanoclusters C12-AgNCs (A,B) and Tel22C12-AgNCs (C,D). Scale bar $10 \mathrm{~nm}(\mathrm{~A}, \mathrm{C}), 2 \mathrm{~nm}(\mathrm{~B}, \mathrm{D})$; Figure S7: UV melting profiles of TBAC12 and TBAC12-AgNCs $(2 \mu \mathrm{M})$ in $10 \mathrm{mM}$ Tris-acetate buffer $(\mathrm{pH}=7.5)$ containing $100 \mathrm{mM} \mathrm{NaCl}$ or $100 \mathrm{mM} \mathrm{KCl}$; monitored at $260 \mathrm{~nm}$ (a) or $295 \mathrm{~nm}$ (b); Figure S8: Excitation spectra at $\lambda_{\mathrm{em}}=630 \mathrm{~nm}$ (a) and emission spectra at $\lambda_{\mathrm{ex}}=580 \mathrm{~nm}$ (b) of C12-AgNCs with cytosine to $\mathrm{Ag}^{+}$ratio 1:1( $\left.\mathrm{Ag}^{+} / \mathrm{C}\right)$; Figure S9: Excitation spectra at $\lambda_{\mathrm{em}}=550 \mathrm{~nm}$ (a) and emission spectra at $\lambda_{\text {ex }}=470 \mathrm{~nm}$ (b) of Tel22C12-AgNCs with cytosine to $\mathrm{Ag}^{+}$ratio 1:1 $\left(\mathrm{Ag}^{+} / \mathrm{C}\right)$; Figure S10: Excitation 
spectra at $\lambda_{\mathrm{em}}=620 \mathrm{~nm}$ (a) and emission spectra at $\lambda_{\mathrm{ex}}=570 \mathrm{~nm}$ (b) of Tel22C12-AgNCs with cytosine to $\mathrm{Ag}^{+}$ratio 1:1 $\left(\mathrm{Ag}^{+} / \mathrm{C}\right)$; Figure S11: Excitation spectra at $\lambda_{\mathrm{em}}=550 \mathrm{~nm}$ (a) and emission spectra at $\lambda_{\text {ex }}=470 \mathrm{~nm}(\mathrm{~b})$ of TBAC12-AgNCs with cytosine to $\mathrm{Ag}^{+}$ratio 1:1 $\left(\mathrm{Ag}^{+} / \mathrm{C}\right)$; Figure S12: Excitation spectra at $\lambda_{\mathrm{em}}=610 \mathrm{~nm}$ (a) and emission spectra at $\lambda_{\mathrm{ex}}=560 \mathrm{~nm}$ (b) of TBAC12-AgNCs with cytosine to $\mathrm{Ag}^{+}$ratio 1:1 $\left(\mathrm{Ag}^{+} / \mathrm{C}\right)$; Figure S13: Influence of $\mathrm{K}^{+}$ions on red emission spectra of TelC22-AgNCs upon addition of $\mathrm{KCl}$ or $\mathrm{KNO}_{3}$; Figure S14: Absorption spectra of Tel22C12-AgNCs with cytosine to $\mathrm{Ag}^{+}$ratio 1:1 $\left(\mathrm{Ag}^{+} / \mathrm{C}\right)$ upon titration with $\mathrm{KCl}(\mathrm{a})$ and $\mathrm{NaCl}(\mathrm{b})$; Figure S15: Absorption spectra of TBAC12-AgNCs with cytosine to $\mathrm{Ag}^{+}$ratio 1:1 $\left(\mathrm{Ag}^{+} / \mathrm{C}\right)$ upon titration with $\mathrm{KCl}$ (a) and $\mathrm{NaCl}(\mathrm{b})$; Figure S16: Circular dichroism spectra of Tel22C12-AgNCs with cytosine to $\mathrm{Ag}^{+}$ratio 1:1 $\left(\mathrm{Ag}^{+} / \mathrm{C}\right)$ upon titration with $\mathrm{KCl}(\mathrm{a})$ and $\mathrm{NaCl}(\mathrm{b})$; Figure S17: Circular dichroism spectra of TBAC12-AgNCs with cytosine to $\mathrm{Ag}^{+}$ratio 1:1 $\left(\mathrm{Ag}^{+} / \mathrm{C}\right)$ upon titration with $\mathrm{KCl}(\mathrm{a})$ and $\mathrm{NaCl}(\mathrm{b})$.

Author Contributions: A.Ś. and A.D. conceived and designed the study. A.Ś. and P.F. carried out the experiments and processed data. G.N. took TEM images. All authors analyzed the data. A.D. wrote the manuscript. P.F., J.K. and A.D. revised manuscript, which was edited by A.D., A.Ś. and P.F. All authors have read and agreed to the published version of the manuscript.

Funding: This research was financially supported by the National Science Centre of Poland, Grant No. 2015/19/N/ST4/00407. Grzegorz Nowaczyk was supported by a grant No. 41/E-336/SPUB/SP/ 2019 from the Polish Ministry of Science and Higher Education.

Institutional Review Board Statement: Not applicable.

Informed Consent Statement: Not applicable.

Data Availability Statement: Data are provided in the manuscript.

Acknowledgments: The authors thank Bernard Juskowiak for mentoring and fruitful discussions.

Conflicts of Interest: The authors declare no conflict of interest.

\section{References}

1. Zhang, Q.; Yang, M.; Zhu, Y.; Mao, C. Metallic Nanoclusters for Cancer Imaging and Therapy. Curr. Med. Chem. 2018, 25, 1379-1396. [CrossRef] [PubMed]

2. Ono, A.; Cao, S.; Togashi, H.; Tashiro, M.; Fujimoto, T.; Machinami, T.; Oda, S.; Miyake, Y.; Okamoto, I.; Tanaka, Y. Specific Interactions between Silver (i) Ions and Cytosine-Cytosine Pairs in DNA Duplexes. Chem. Commun. 2008, 39, $4825-4827$. [CrossRef] [PubMed]

3. Wu, J.; Fu, Y.; He, Z.; Han, Y.; Zheng, L.; Zhang, J.; Li, W. Growth Mechanisms of Fluorescent Silver Clusters Regulated by Polymorphic DNA Templates: A DFT Study. J. Phys. Chem. B 2012, 116, 1655-1665. [CrossRef] [PubMed]

4. Petty, J.T.; Zheng, J.; Hud, N.V.; Dickson, R.M. DNA-Templated Ag Nanocluster Formation. J. Am. Chem. Soc. 2004, 126, 5207-5212. [CrossRef]

5. Berti, L.; Burley, G.A. Nucleic acid and nucleotide-mediated synthesis of inorganic nanoparticles. Nat. Nanotechnol. 2008, 3, 81-87. [CrossRef]

6. Shukla, S.; Sastry, M. Probing Differential $\mathrm{Ag}^{+}-$Nucleobase Interactions with Isothermal Titration Calorimetry (ITC): Towards Patterned DNA Metallization. Nanoscale 2009, 1, 122-127. [CrossRef]

7. Li, W.; Liu, L.; Fu, Y.; Sun, Y.; Zhang, J.; Zhang, R. Effects of Polymorphic DNA on the Fluorescent Properties of Silver Nanoclusters. Photochem. Photobiol. Sci. 2013, 12, 1864-1872. [CrossRef]

8. Chen, Y.; Phipps, L.M.; Werner, J.H.; Chakraborty, S.; Martinez, J.S. DNA Templated Metal Nanoclusters: From Emergent Properties to Unique Applications. Acc. Chem. Res. 2008, 51, 12756-12763. [CrossRef] [PubMed]

9. New, S.Y.; Lee, S.T.; Su, X.D. DNA-templated silver nanoclusters: Structural correlation and fluorescence modulation. Nanoscale 2016, 8, 17729-17746. [CrossRef]

10. Zhou, Z.; Du, Y.; Dong, S. DNA-Ag nanoclusters as fluorescence probe for turn-on aptamer sensor of small molecules. Biosens. Bioelectron. 2011, 28, 33-37. [CrossRef]

11. Alipour, M.; Jalili, S.; Shirzad, H.; Dezfouli, E.A.; Fouani, M.H.; Sadeghan, A.A.; Bardania, H.; Hosseinkhani, S. Development of dual-emission cluster of Ag atoms for genetically modified organisms detection. Mikrochim. Acta 2020, 187, 628, Erratum in 2020, 187, 662. [CrossRef]

12. Han, G.M.; Jia, Z.Z.; Zhu, Y.J.; Jiao, J.J.; Kong, D.M.; Feng, X.Z. Biostable L-DNA-Templated Aptamer-Silver Nanoclusters for Cell-Type-Specific Imaging at Physiological Temperature. Anal. Chem. 2016, 88, 10800-10804. [CrossRef] [PubMed]

13. Reyes-Reyes, E.M.; Teng, Y.; Bates, P. A new paradigm for aptamer therapeutic AS1411 action: Uptake by macropinocytosis and its stimulation by a nucleolin-dependent mechanism. J. Cancer Res. 2010, 70, 8617-8629. [CrossRef] [PubMed]

14. Soundararajan, S.; Chen, W.; Spicer, E.K.; Courtenay-Luck, N.; Fernandes, D. The nucleolin targeting aptamer AS1411 destabilizes Bcl-2 messenger RNA in human breast cancer cells. J. Cancer Res. 2008, 68, 2358-2365. [CrossRef] [PubMed] 
15. Sharma, J.; Yeh, H.-C.; Yoo, H.; Werner, J.H.; Martinez, J.S. DNA Silver nanocluster aptamers: In situ generation of intrinsically fluorescent recognition ligands for protein detection. Chem Comm 2011, 47, 2294-2296.

16. Luu, K.N.; Phan, A.T.; Kuryavyi, V.; Lacroix, L.; Patel, D.J. Structure of the human telomere in $\mathrm{K}^{+}$solution: An intramolecular (3+1) G-quadruplex scaffold. J. Am. Chem. Soc. 2006, 128, 9963-9970. [CrossRef]

17. Phan, A.T.; Kuryavyi, V.; Luu, K.N.; Patel, D.J. Structure of two intramolecular G-quadruplexes formed by natural human telomere sequences in $\mathrm{K}^{+}$solution. Nucleic Acids Res. 2007, 35, 6517-6525. [CrossRef]

18. Wang, Y.; Patel, D.J. Solution structure of the human telomeric repeat d[AG(3)(T2AG3)3] G-tetraplex. Structure 1993, 1, $263-282$. [CrossRef]

19. Bock, L.C.; Griffin, L.C.; Latham, J.A.; Vermaas, E.H.; Toole, J.J. Selection of single-stranded-DNA molecules that bind and inhibit human thrombin. Nature 1992, 355, 564-566. [CrossRef]

20. Schultze, P.; Macaya, R.F.; Feigon, J. 3-Dimensional solution structure of the thrombin-binding DNA aptamer d (GGTTGGTGTGGTTGG). J. Mol. Biol. 1994, 235, 1532-1547. [CrossRef]

21. Wang, K.Y.; Krawczyk, S.H.; Bischofberger, N.; Swaminathan, S.; Bolton, P.H. The tertiary structure of a DNA aptamer which binds to and inhibits thrombin determines activity. Biochemistry 1993, 32, 11285-11292. [CrossRef] [PubMed]

22. Nagatoishi, S.; Nojima, T.; Juskowiak, B.; Takenaka, S. A Pyrene-labeled G-quadruplex oligonucleotide as a fluorescence probe for potassium ions detection in biological applications. Angew. Chem. 2005, 44, 5067-5070. [CrossRef]

23. He, F.; Tang, Y.; Wang, S.; Li, Y.; Zhu, D. Fluorescent Amplifying Recognition for DNA G-Quadruplex Folding with a Cationic Conjugated Polymer: A Platform for Homogeneous Potassium Detection. J. Am. Chem. Soc. 2005, 127, 12343-12346. [CrossRef] [PubMed]

24. Nagatoishi, S.; Nojima, T.; Galezowska, E.; Juskowiak, B.; Takenaka, S. G-quadruplex-based FRET probes with the thrombinbinding aptamer (TBA) sequence designed for the efficient fluorometric detection of the potassium ion. ChemBioChem 2006, 7 , 1730-1737. [CrossRef] [PubMed]

25. Kong, D.; Guo, J.; Yang, W.; Ma, Y.; Shen, H. Crystal violet-G-quadruplex complexes as fluorescent sensors for homogeneous detection of potassium ion. Biosens. Bioelectron. 2009, 25, 88-93. [CrossRef]

26. Ohtsuka, S.K.; Sato, S.; Sato, Y.; Sota, K.; Ohzawa, S.; Matsuda, T.; Takemoto, K.; Takamune, N.; Juskowiak, B.; Nagaib, T.; et al. Fluorescence imaging of potassium ions in living cells using a fluorescent probe based on a thrombin binding aptamer-peptide conjugate. Chem. Commun. 2012, 48, 4740-4742. [CrossRef] [PubMed]

27. Switalska, A.; Dembska, A.; Fedoruk-Wyszomirska, A.; Juskowiak, B. Cholesterol-Bearing Fluorescent G-Quadruplex Potassium Probes for Anchoring at the Langmuir Monolayer and Cell Membrane. Sensors 2018, 18, 2201-2219. [CrossRef]

28. Takenaka, S. Detection of tetraplex DNA and detection by tetraplex DNA. Anal. Sci. 2021, 37, 9-15. [CrossRef]

29. Tietz, N.W. Fundamentals of Clinical Chemistry; W.B. Saunders Company: Philadelphia, PA, USA, $1976 ;$ pp. 875-877.

30. Ritchie, C.M.; Johnsen, K.R.; Kiser, J.R.; Antoku, Y.; Dickson, R.M.; Petty, J.T. Ag Nanocluster Formation Using a Cytosine Oligonucleotide Template. J. Phys. Chem. C 2007, 111, 175-181. [CrossRef]

31. Dembska, A.; Switalska, A.; Fedoruk-Wyszomirska, A.; Juskowiak, B. Development of fluorescence oligonucleotide probes based on cytosine- and guanine-rich sequences. Sci. Rep. 2020, 10, 11006-11018. [CrossRef]

32. Richards, C.I.; Choi, S.; Hsiang, J.C.; Antoku, Y.; Vosch, T.; Bongiorno, A.; Tzeng, Y.L.; Dickson, R.M. Oligonucleotide stabilized Ag nanocluster fluorophore. J. Am. Chem. Soc. 2008, 130, 5038-5039. [CrossRef]

33. Daune, M.; Dekker, C.A.; Schachman, H.K. Complexes of Silver Ion with Natural and Synthetic Polynucleotides. Biopolymers 1966, 4, 51-76. [CrossRef]

34. Petty, J.T.; Story, S.P.; Hsiang, J.C.; Dickson, R.M. DNA-Templated Molecular Silver Fluorophores. J. Phys. Chem. Lett. 2013, 4, 1148-1155. [CrossRef] [PubMed]

35. Soto-Verdugo, V.; Metiu, H.; Gwinn, E. The Properties of Small Ag Clusters Bound to DNA Bases. J. Chem. Phys. 2010, 132, 195102. [CrossRef] [PubMed]

36. Manzini, G.; Yathindra, N.; Xodo, L.E. Evidence for intramolecularly folded i-DNA structures in biologically relevant CCCrepeat sequences. Nucleic Acids Res. 1994, 22, 4634-4640. [CrossRef] [PubMed]

37. Simonsson, T.; Pribylova, M.; Vorlickova, M. A Nuclease Hypersensitive Element in the Human c-myc Promoter Adopts Several Distinct i-Tetraplex Structures. Biochem. Biophys. Res. Commun. 2000, 278, 158-166. [CrossRef] [PubMed]

38. Pagano, B.; Martino, L.; Randazzo, A.; Giancola, C. Stability and binding properties of a modified thrombin binding aptamer. Biophys. J. 2008, 94, 562-569. [CrossRef]

39. Nagatoishi, S.; Isono, N.; Tsumoto, K.; Sugimoto, N. Loop residues of thrombin-binding DNA aptamer impact G-quadruplex stability and thrombin binding. Biochimie 2011, 93, 1231-1238. [CrossRef] [PubMed]

40. Sacca, B. The Effect of Chemical Modifications on the Thermal Stability of Different G-Quadruplex-Forming Oligonucleotides. Nucleic Acids Res. 2005, 33, 1182-1192. [CrossRef]

41. Tao, Y.; Li, M.; Ren, J.; Qu, X. Metal nanoclusters: Novel probes for diagnostic and therapeutic applications. Chem. Soc. Rev. 2015, 44, 8636-8663. [CrossRef] [PubMed]

42. Chen, Z.; Tan, L.; Hu, L.; Luan, Y. Superior fluorescent probe for detection of potassium ion. Talanta 2015, 144, 247-251. [CrossRef] [PubMed] 
43. Rastegar, A. Serum Potassium. In Clinical Methods: The History, Physical, and Laboratory Examinations, 3rd ed.; Walker, H.K., Hall, W.D., Hurst, J.W., Eds.; Butterworths: Boston, MA, USA, 1990; Chapter 195. Available online: https://www.ncbi.nlm.nih.gov/ books /NBK307/ (accessed on 30 October 2021).

44. Gwinn, E.G.; O’Neill, P.; Guerrero, A.J.; Bouwmeester, D.; Fygenson, D.K. Sequence-Dependent Fluorescence of DNA-Hosted Silver Nanoclusters. Adv. Mater. 2008, 20, 279-283. [CrossRef]

45. Sengupta, B.; Ritchie, C.M.; Buckman, J.G.; Johnsen, K.R.; Goodwin, P.M.; Petty, J.T. Base-Directed Formation of Fluorescent Silver Clusters. J. Phys. Chem. C 2008, 112, 18776-18782. [CrossRef] [PubMed] 